\title{
Analysis of Territorial Accessibility to the Nodes of Health Activity in the Municipality of Pitalito, Colombia
}

\author{
Diego A. Escobar ${ }^{1}$, Jorge A. Montoya ${ }^{1} \&$ Carlos A. Moncada ${ }^{2}$ \\ ${ }^{1}$ Universidad Nacional de Colombia, Sede Manizales, Facultad de Ingeniería y Arquitectura, Departamento de \\ Ingeniería Civil, Carrera 27 \# 64-60, Manizales, Colombia \\ ${ }^{2}$ Universidad Nacional de Colombia, Sede Bogotá. Facultad de Ingeniería, Departamento de Ingeniería Civil y \\ Agrícola, Ciudad Universitaria edificio 214 oficina 417, Bogotá, Colombia \\ Correspondence: Diego A. Escobar, Universidad Nacional de Colombia, Sede Manizales. Facultad de Ingeniería \\ y Arquitectura, Departamento de Ingeniería Civil, Carrera 27 \# 64-60, Manizales, 170004, Colombia. E-mail: \\ daescobarga@unal.edu.co
}

Received: July 10, 2018 Accepted: August 14, 2018 Online Published: August 31, 2018

doi:10.5539/gjhs.v10n10p1 URL: https://doi.org/10.5539/gjhs.v10n10p1

The research is financed by Universidad Nacional de Colombia, Facultad de Ingeniería y Arquitectura.

\begin{abstract}
The current population growth links different social and economic development problems that must be addressed, within these public health, which should be of high priority in order to minimize the threats of health in the citizenry; therefore, administrative entities must get strong commitments in minimum periods of time. Taking into account the above, it is proposed to evaluate the level of accessibility offered by the road infrastructure network in the municipality of Pitalito, department of Huila, as well as the level of coverage by population and area for the years 2015 (base scenario) and 2031 (intervened scenario), through the use of geostatistical methods from digital tools.
\end{abstract}

Keywords: accessibility, health, road infrastructure, geostatistics, coverage

\section{Introduction}

The municipality of Pitalito, is located south of the department of Huila on the Magdalena valley at $1^{\circ} 51^{\prime} 14$ "north latitude and $76^{\circ} 03^{\prime} 05^{\prime}$ " west longitude (Figure 1), and rests on the vertex of origin of the eastern and central mountain ranges at 1318 masl having an average temperature of $19^{\circ}$ (Alcaldía de Pitalito, 2012). The municipality has a total area of $666 \mathrm{~km} 2$ (Alcaldía de Pitalito, 2012) on which 125839 inhabitants reside (Departamento Administrativo Nacional de Estadistica, 2015), with 79.5\% of urban character, distributed in 4 communes.

Its connection with the capital of the department is centered on a $188 \mathrm{~km}$ road corridor in good condition (Alcaldía de Pitalito, 2012), however, the existing length generates the immediate need to maximize the use of health equipment, minimizing the transfer requirements to higher order entities.

In matters of health, $66.56 \%$ of the population is affiliated to the subsidized regime, $26.28 \%$ to the contributory regime and $7.16 \%$ does not have any connection (Alcaldía de Pitalito, 2012); in relation to mortality, there has been a gradual reduction since 2003, going from 63.4 deaths per 100000 inhabitants to 34.3 per 100000 inhabitants to 201, the main causes being: chronic diseases, violent deaths and cancer (Alcaldía de Pitalito, 2015).

The needs of access to health equipment implies a strong commitment from the municipal administration, with the aim of achieving a healthier population by minimizing travel time to these services (Unal, Chen, \& Waldorf, 2007), in addition to guaranteeing a better quality of life. For this reason it is proposed to perform the assessment of accessibility to the health care centers of the municipality, taking into account the baseline situation (2015), as well as the horizon 2031, after the road interventions proposed by the administration in its Land Management Plan, still under construction.

The concept of "accessibility", in its basic form, contemplates the measurement of the ease or difficulty existing for communication between human settlements, according to the activities to be carried out taking as reference the transport modes and road infrastructure used (Morris, Dumble, \& Wigan, 1978). Other forms of reference to the 
term relate it to the intensity of possibilities for interaction and exchange (Hansen, 1959; Enwicht, 1993); considering as elements of interaction, the population, infrastructure and health facilities, configured as origin, destination and trajectory (Monzón de Cáceres, 1988).
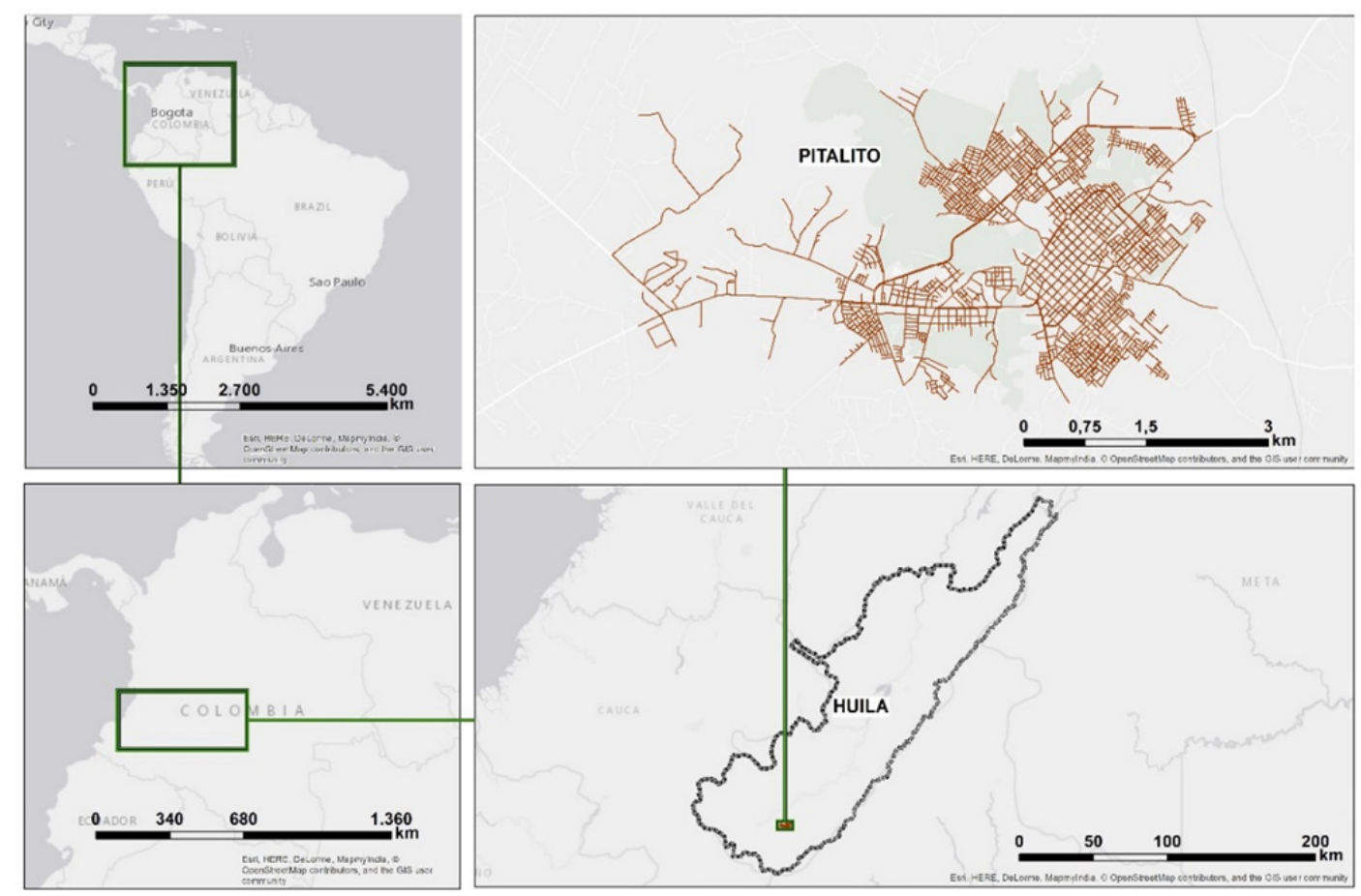

Figure 1. Location of the municipality of Pitalito, Huila

Some studies related to accessibility in our medium of study are: social exclusion (Bocarejo, \& Oviedo, 2012), sustainability (Cheng, Bertolini, \& Clercq, 2007; Vega, 2011), agriculture and natural resources (Gellrich \& Zimmermann, 2007), trade (Montoya, Escobar, \& Moncada, 2017; Montoya, Escobar, \& Sabogal, 2017; Zuluaga \& Escobar, 2016), health (Putri, Permanasari, \& Fauziati, 2016; Rosero, 2004; Unal et al., 2007), among others.

\section{Method}

As a research methodology, the application of $\mathrm{xx}$ consecutive items is considered, which takes in account significant elements for the study, from the collection of information, to the construction of coverage graphs as shown in Figure 2. 


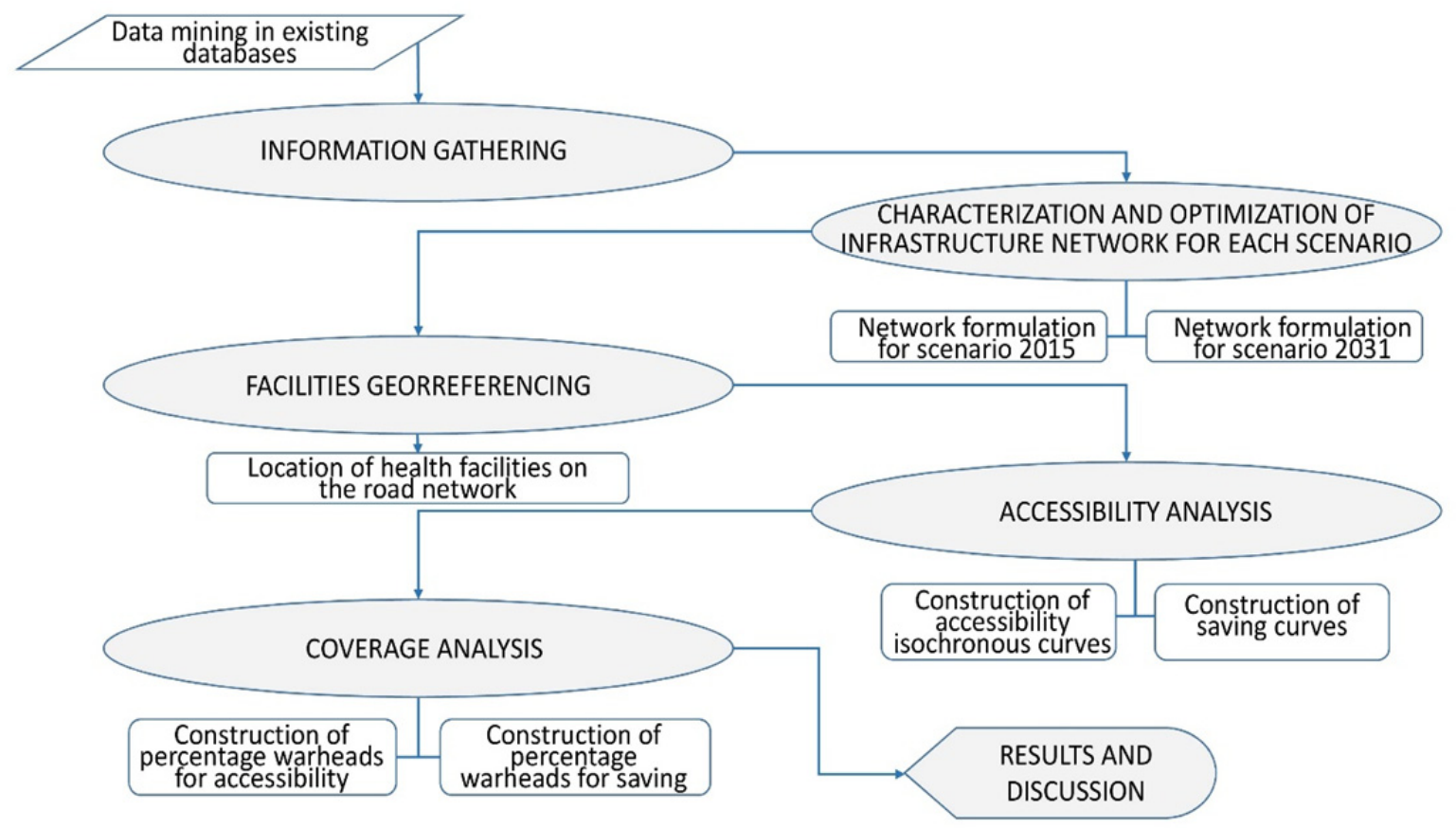

Figure 2. Applied research methodology

\subsection{Information Gathering}

As a first methodological item, we proceed to collect the necessary information for the characterization of the road network and health facilities; within which the different physical and operative components are considered for the current and future base.

\subsection{Characterization and Optimization of the Road Network for Each Scenario}

After obtaining the physical and operational characteristics of the municipality's infrastructure network (speed, directionality, length, type, etc.), the road network of each scenario is formulated.

\subsubsection{Current Scenario (2015)}

Figure 3 shows the configuration of the road network of the municipality of Pitalito for the current situation (2015), considering the physical and operational characteristics collected in the previous item. It is important to clarify that within the structure of the road network, two vital elements are distinguished for the use of the network, nodes (elements of virtual union between roads) and arcs (linear elements that represent a track segment). 


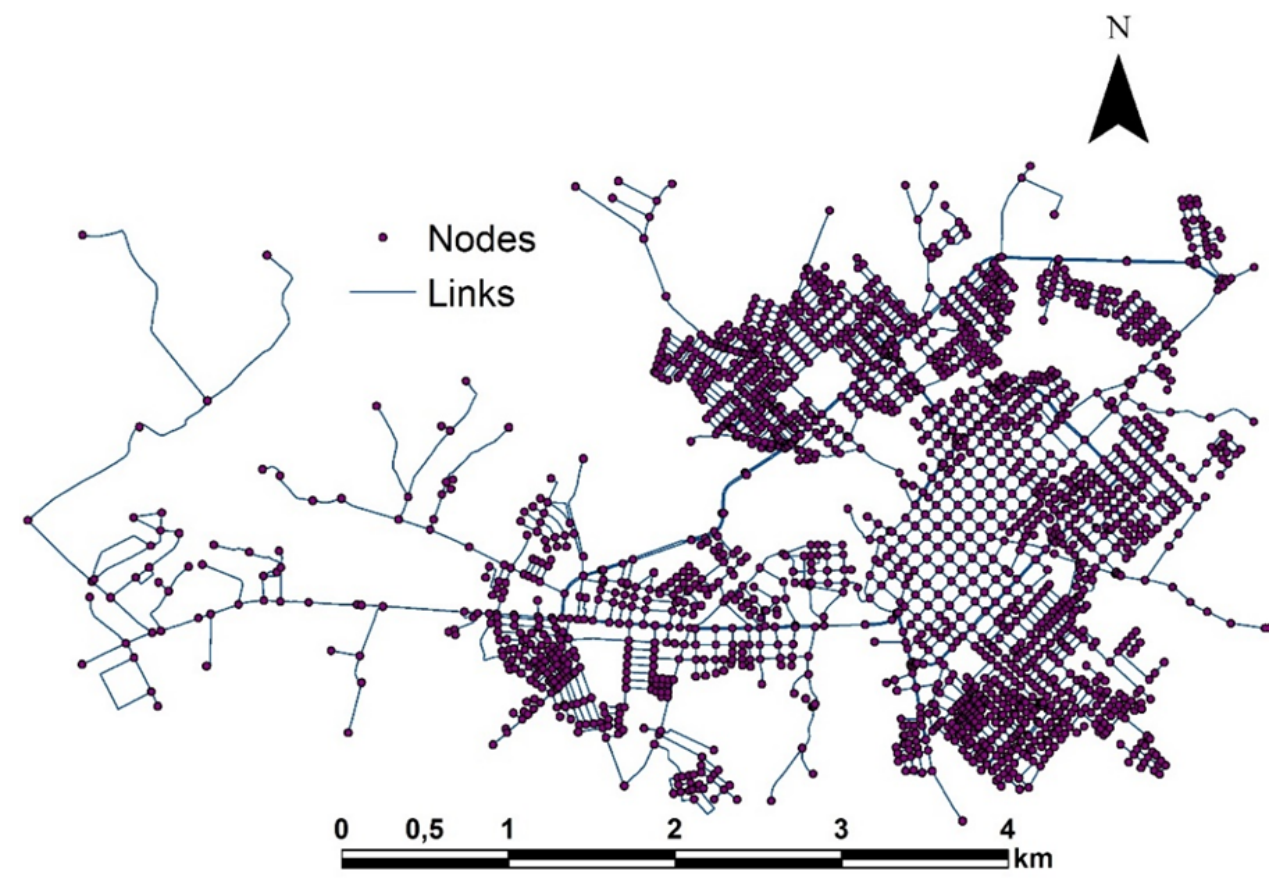

Figure 3. Road network configuration for scenario 2015

\subsubsection{Future Scenario (2031)}

After the formulation of the base network, we proceed to generate the sequence of links and nodes for the expansion of the infrastructure network to the future scenario, taking into account road rings, expansions and elevated sections. The interventions are carried out using the ArcMap tool and can be seen in Figure 4 .

\subsection{Georeferencing of Equipment}

Another of the necessary inputs for the execution of the evaluation is the georeferencing of the nodes of activity in health obtained through the mining of data of the methodological item 1; which are seen in Figure 5.

\subsection{Accessibility Analysis}

\subsubsection{Construction of Accessibility Curves}

As a next methodological item, equipment and infrastructure networks are linked to formulate the accessibility curves using the ArcMap tool; within this, the links acquire the denomination of "incidents", the health care centers as "facilities" and the links as "Routes" (Montoya et al., 2017). The construction of these curves, focuses on the determination of travel times ( $\mathrm{Tt}$ ), which, using equation 1 calculates the cost of moving on each link of the road network, considering the length of the link (X) and its speed (V). 


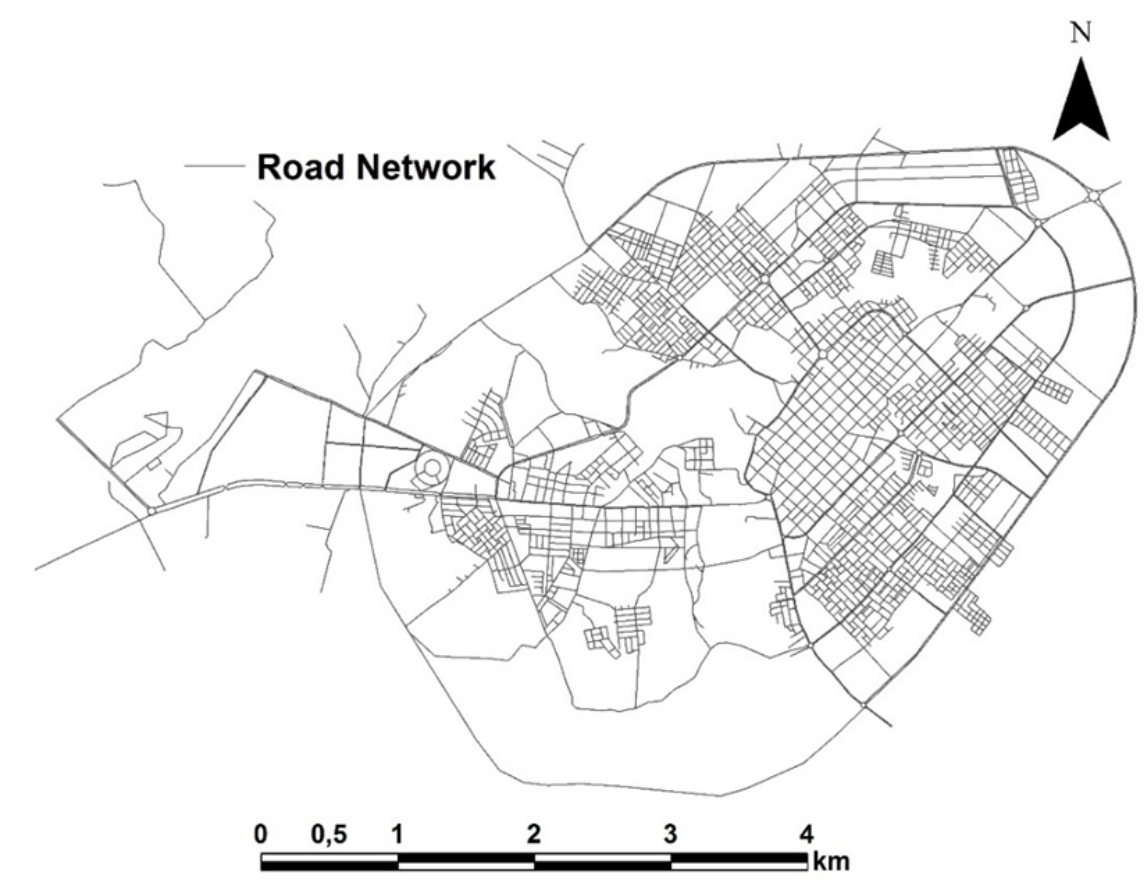

Figure 4. Road network for future scenario, 2031

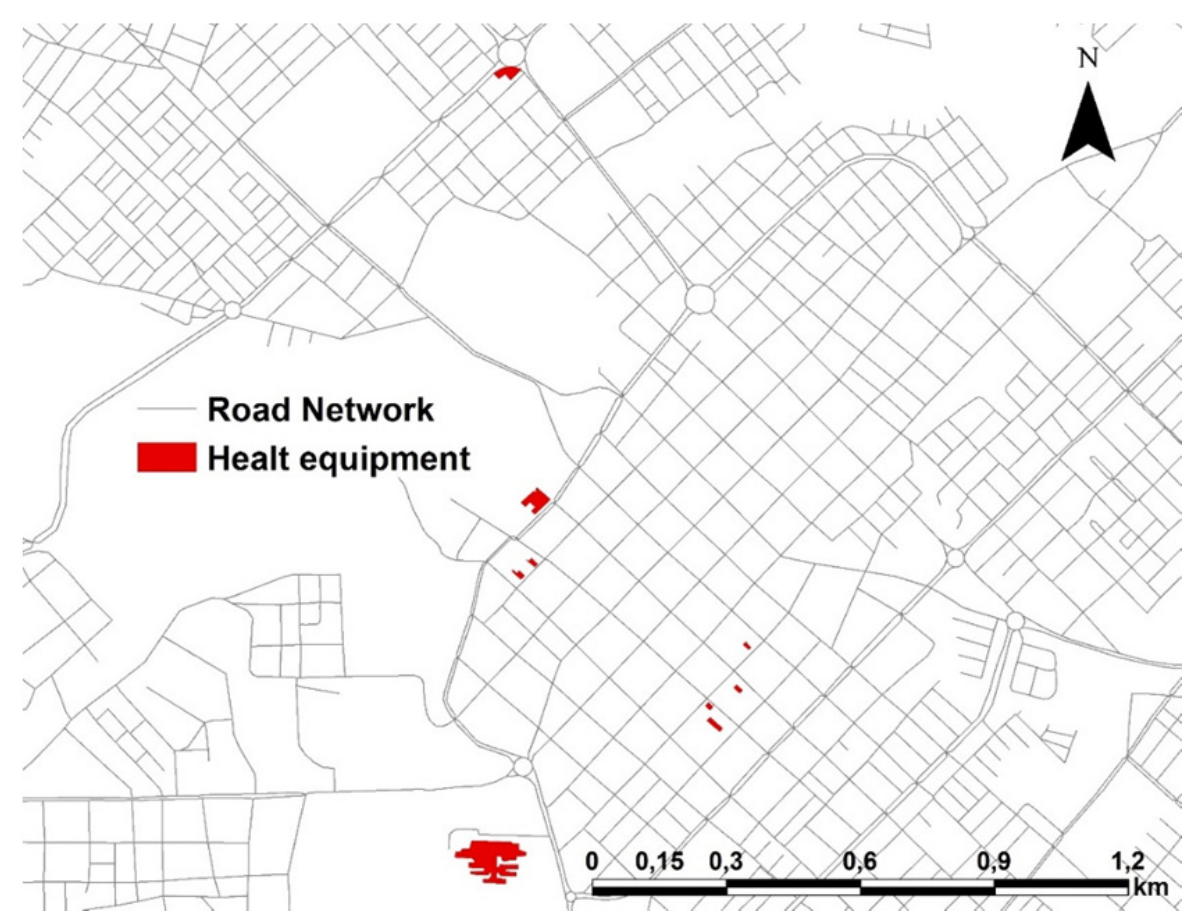

Figure 5. Health activity nodes location

$$
T t_{i}=\frac{X_{i}}{V_{i}} \quad i=1,2,3,4, \ldots, n
$$

Subsequently, the Closest facility tool immersed in the Network Analyst extension of ArcMap is executed, which, through the application of the Dijkstra algorithm, obtains the lowest cost of moving from a source node to a destination one (Montoya et al., 2017; Perilla, Escobar, \& Cardona, 2017; Sallán, Guardient, \& Suñé, 2010). With the values obtained for each facility, the vector of displacement times is obtained, which crossed with the spatial location of each node, formalizes the displacement time matrix. 
Finally, the Geostatical Wizard tool is executed, which links the displacement time matrix and, through the ordinary Kriging interpolation method, elaborates the accessibility curves.

\subsubsection{Construction of Savings Curves}

Once the displacement times have been determined and the accessibility curves have been constructed for each scenario, we proceed to evaluate the savings percentage (Savings in time) generated by road interventions by 2031 . The construction process considers the relationship in times of displacement of the future scenario $\left(T t_{i(f u t)}\right)$ with respect to the current scenario $\left(T t_{i(a c t)}\right)$, using equation 2 .

$$
\text { Savings in time }(\%)=\left(\frac{T t_{i(a c t)}-T t_{i(f u t)}}{t v_{i(a c t)}}\right) * 100
$$

With the savings values obtained, we proceed to execute the Geostatical Wizard tool, as in the elaboration of the accessibility curves, to finally obtain the graphic representation of the savings generated.

\subsection{Coverage Analysis}

As a last methodological item, we proceed to link the socioeconomic variables of area and population, obtained during the data mining of item 1 , which are distributed over a graphic entity (shape) type polygon, with which we proceed to intercept the accessibility and savings curves obtained, using the Geoprocesing intersect tool of ArcMap.

\section{Results}

\subsection{Accessibility Analysis in the Current Scenario (2015)}

As a result of the analysis of territorial accessibility of the health care nodes in the municipality of Pitalito for the base situation, 2015, Figure 6 was obtained, in which the variation in travel time generated by the road network at intervals of 0.5 minutes is appreciated.

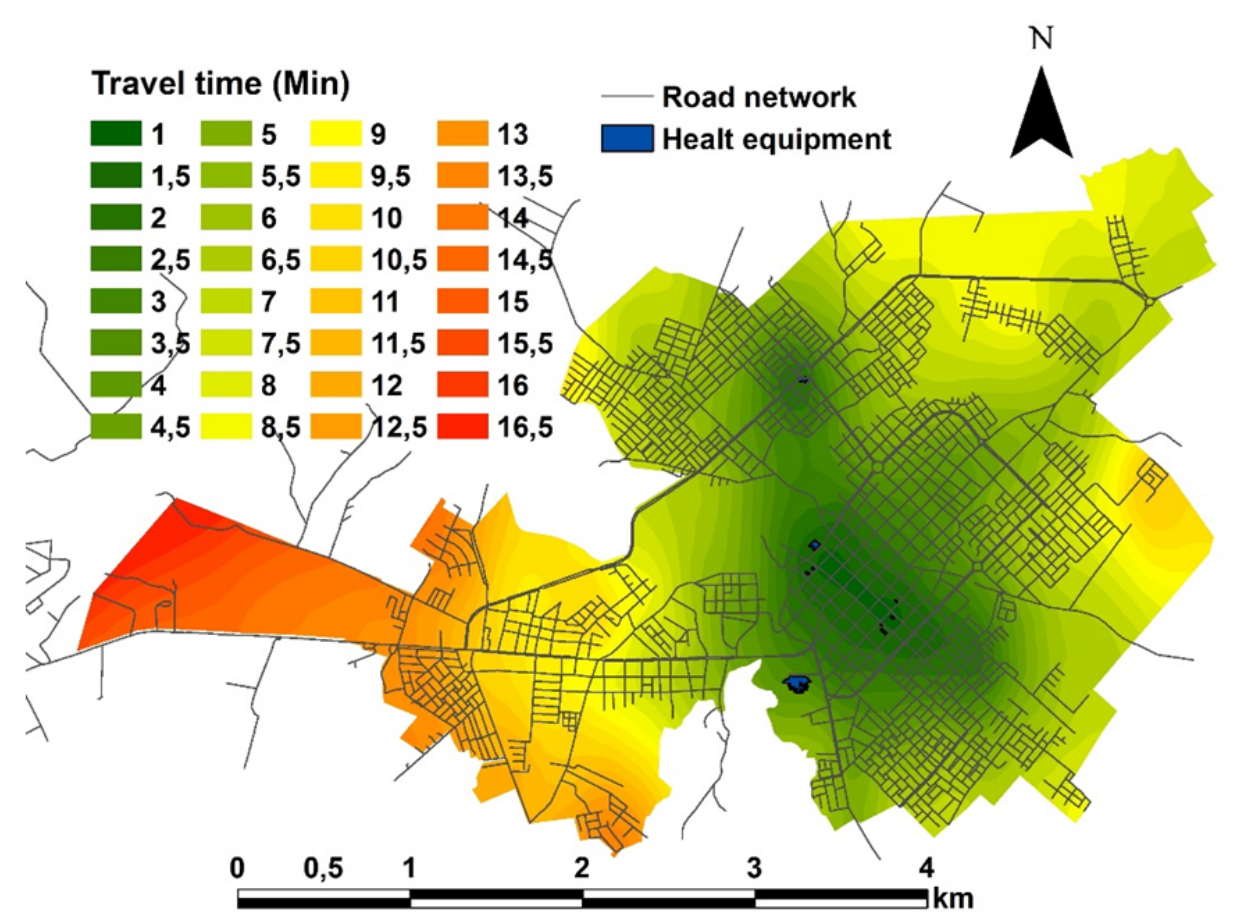

Figure 6. Territorial accessibility curves for the current scenario, 2015

There is a high percentage of the municipality covered by a travel time of less than 8 minutes (eastern sector), which guarantees quick access to at least one of the health entities. On the other hand, there is an observed maximum of 16 minutes towards the western part of the municipality, which shows the need for intervention, either in infrastructure or generation of a new health center.

Figure 7 shows the percentage of coverage by population and area generated by the infrastructure network to 
health facilities, managing to cover $70 \%$ of both variables in less than 7 minutes, in addition to a similar behavior between curves, which can be interpreted as a balanced distribution of the population on the surface of the municipality.

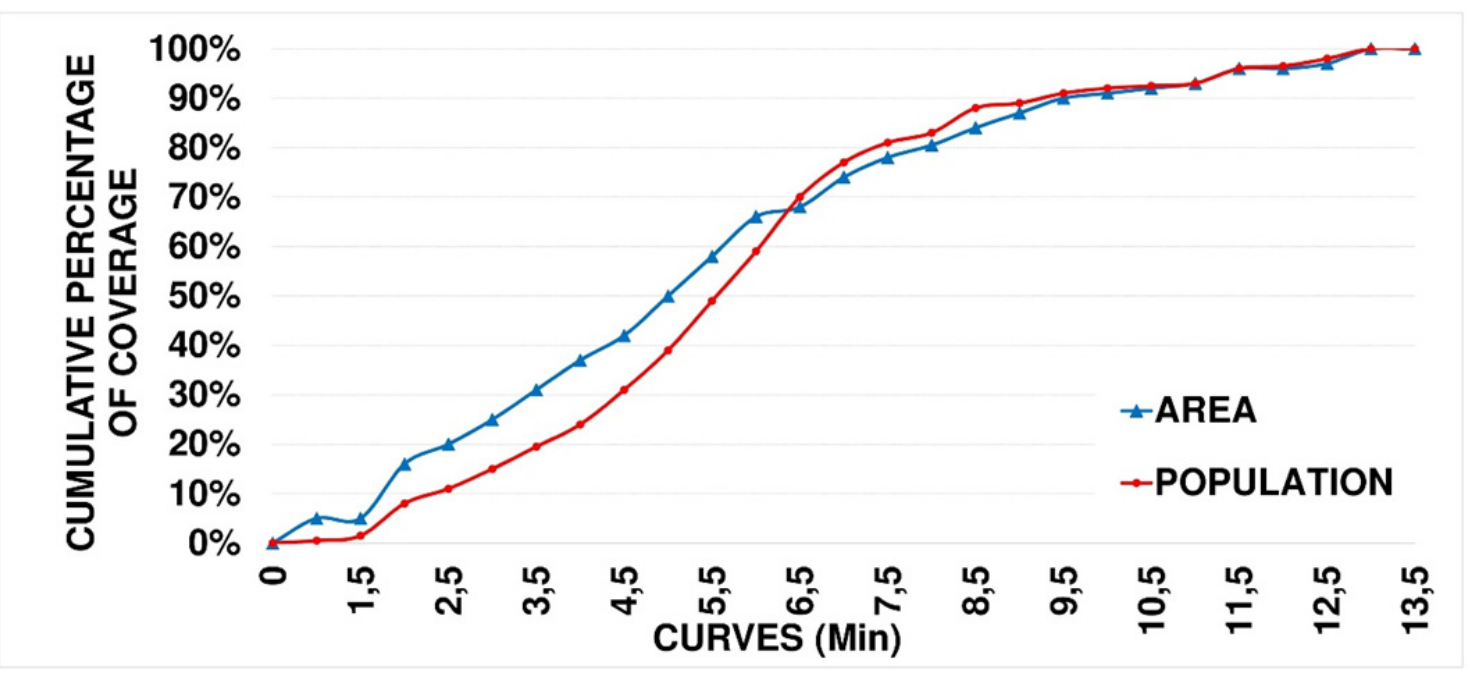

Figure 7. Accumulated percentage of coverage by variable to 2015

\subsection{Future Scenario (2031)}

As a result of the evaluation of accessibility to health facilities once the road interventions to the 2031 horizon have been established, Figure 8 is presented, where the variation in the displacement cost obtained can be seen at 2.5 -minute intervals.

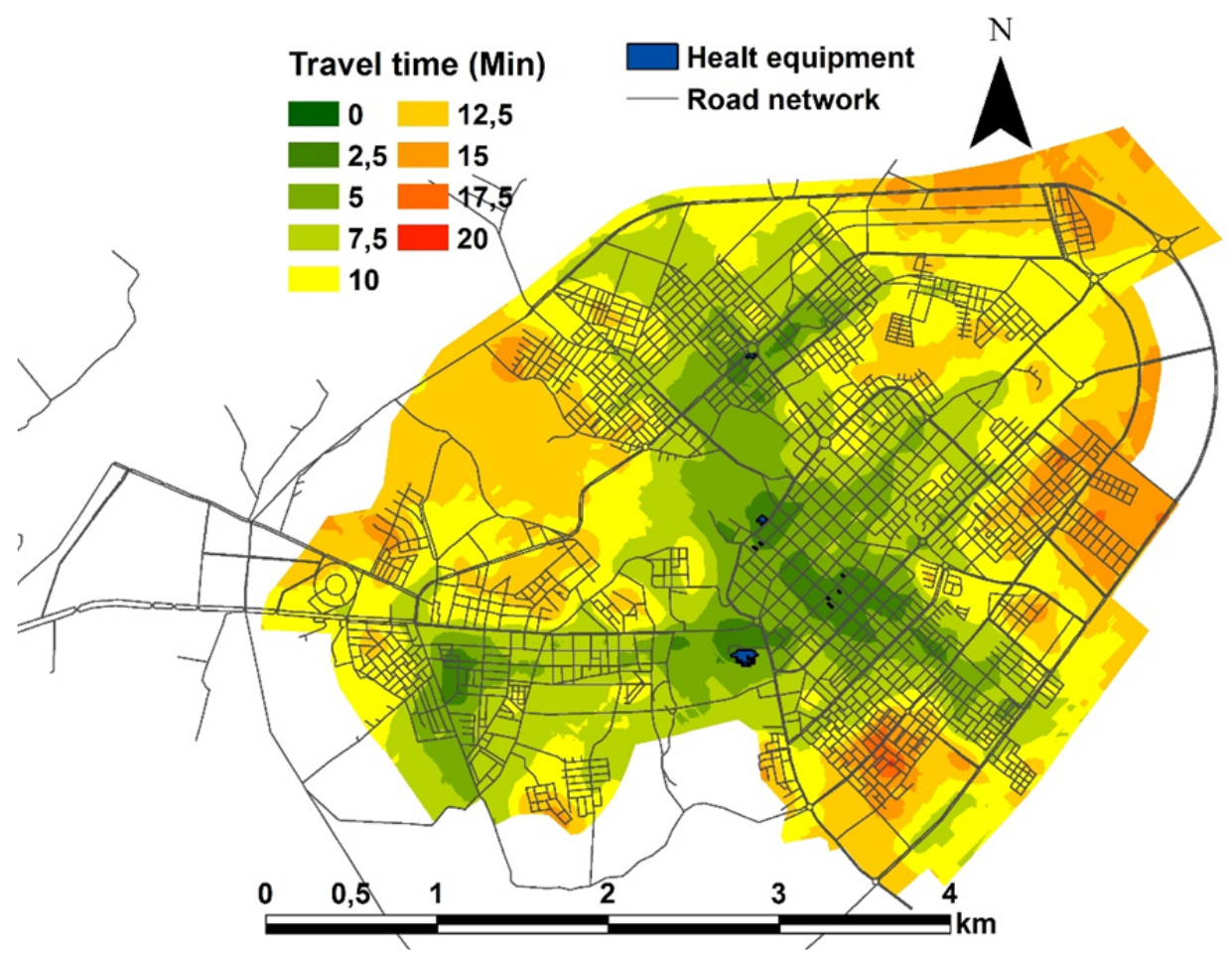

Figure 8. Territorial accessibility curves for the future scenario, 2031

A strong coverage concentration of less than 8 minutes is identified, around $45 \%$ of the total map, towards the 
sectors with the highest population density in the road network. The peripheral and expansion sectors in the network require a higher displacement cost, however, low density is evident, which is why there is no displacement deficit; additionally, the mark in coverage of the western sector observed in Figure 6 is suppressed, because this acquires the connotation of industrial zone and requires a differentiated treatment.

Complementarily, in Figure 9, the results obtained from coverage by population and area are shown, the similarity between curves with respect to Figure 7, increased, presenting a discrepancy of $10 \%$ at 10 minutes. Regarding coverage percentages, $70 \%$ of the variables are framed in a travel time of less than 10 minutes, which when compared to the current scenario, increases the cost in time for the same coverage margin; however, it must be considered that at the 2031 horizon the population value increases to 150432 inhabitants (Consorcio Aguas del Huila, 2014).

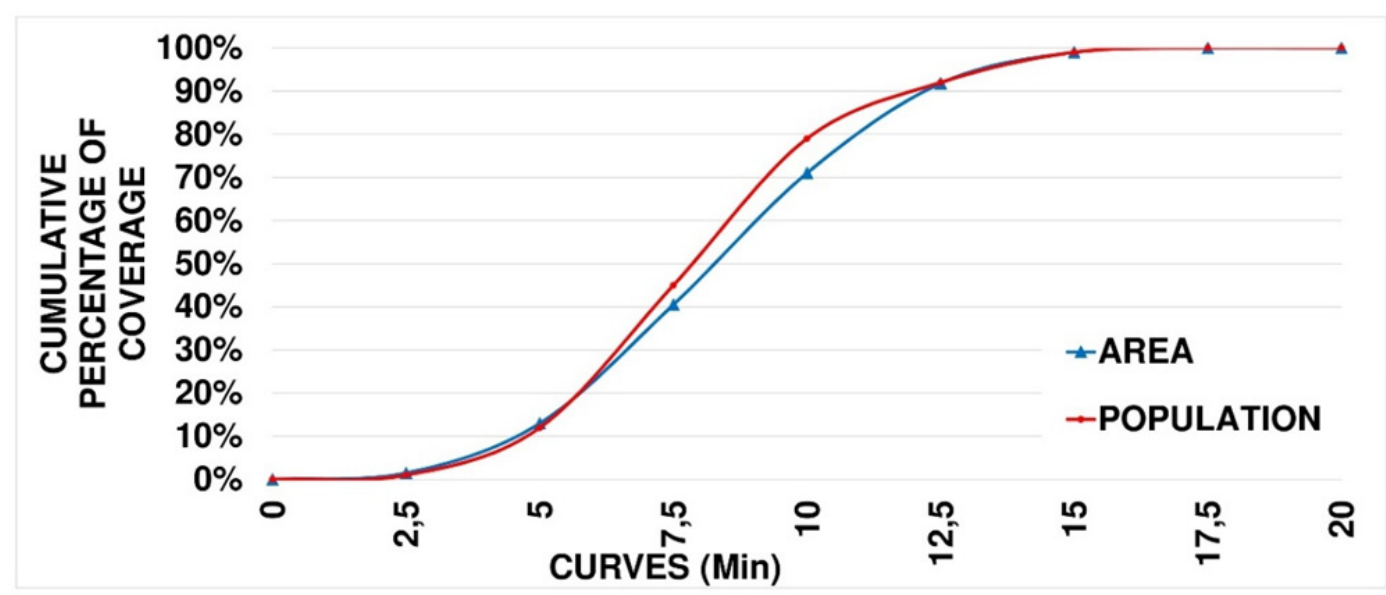

Figure 9. Accumulated percentage of coverage by variable to 2031

\subsection{Savings percentage}

Taking into account the accessibility results obtained for the 2015 and 2031 scenarios, it was possible to construct Figure 10, which shows the percentage of savings generated by road interventions at intervals of 10 units.

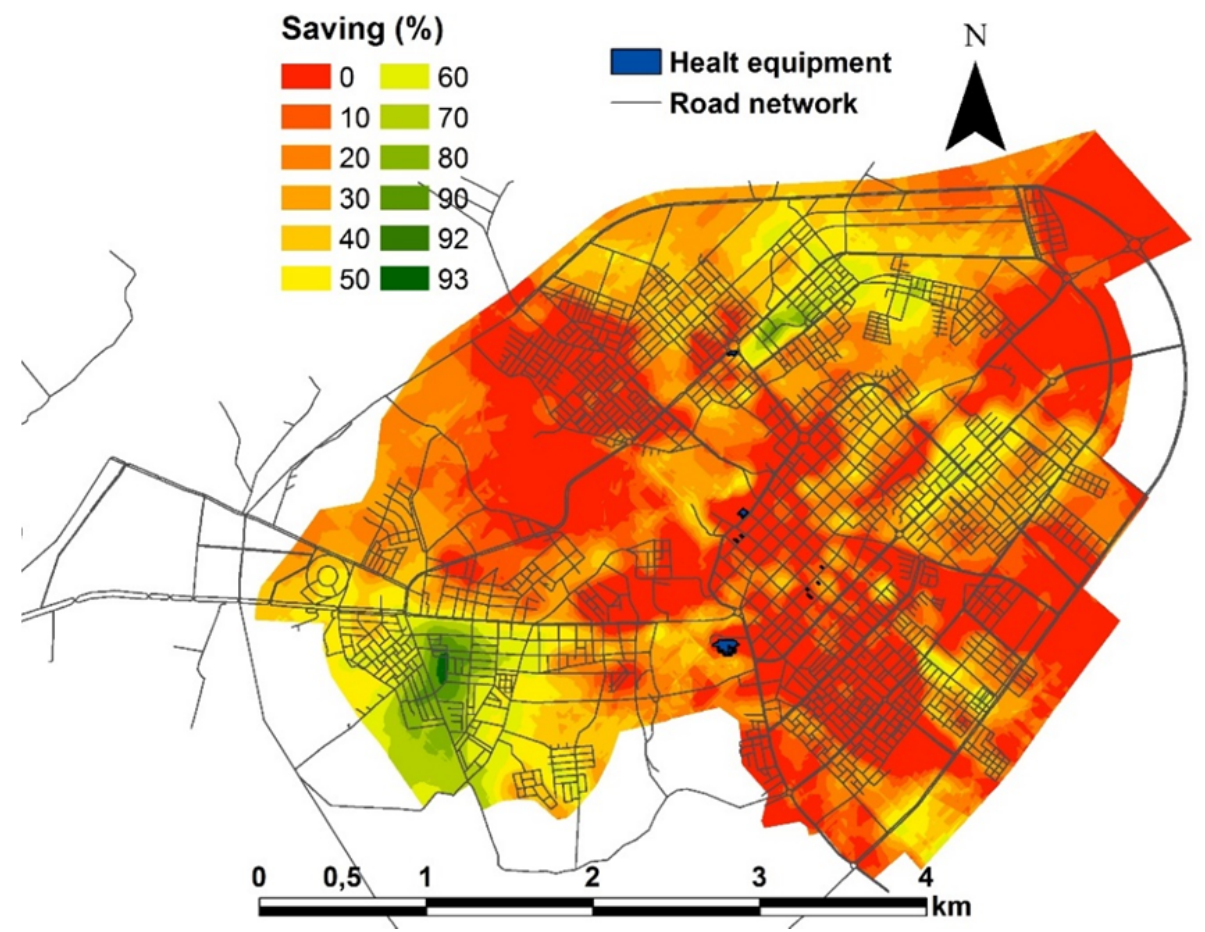

Figure 10. Curves of percentage of savings for health equipment to the 2031 horizon 
It is appreciated that around $60 \%$ of the surface perceives savings of at least $10 \%$, with the southwest sector having the highest value with perceptions of up to $93 \%$. The sectors that do not perceive savings do not imply a deterioration in the mobility of the population, however, it is possible to access the health entities within an established limit of 10 minutes, which could be reduced in a possible intervention.

Figure 11 shows the results obtained for the perception of savings per variable; from which it can be observed that around $50 \%$ of the population perceives a saving of up to $25 \%$, which can be assumed as having a high impact, considering the population growth and the distance in years with respect to the horizon study.

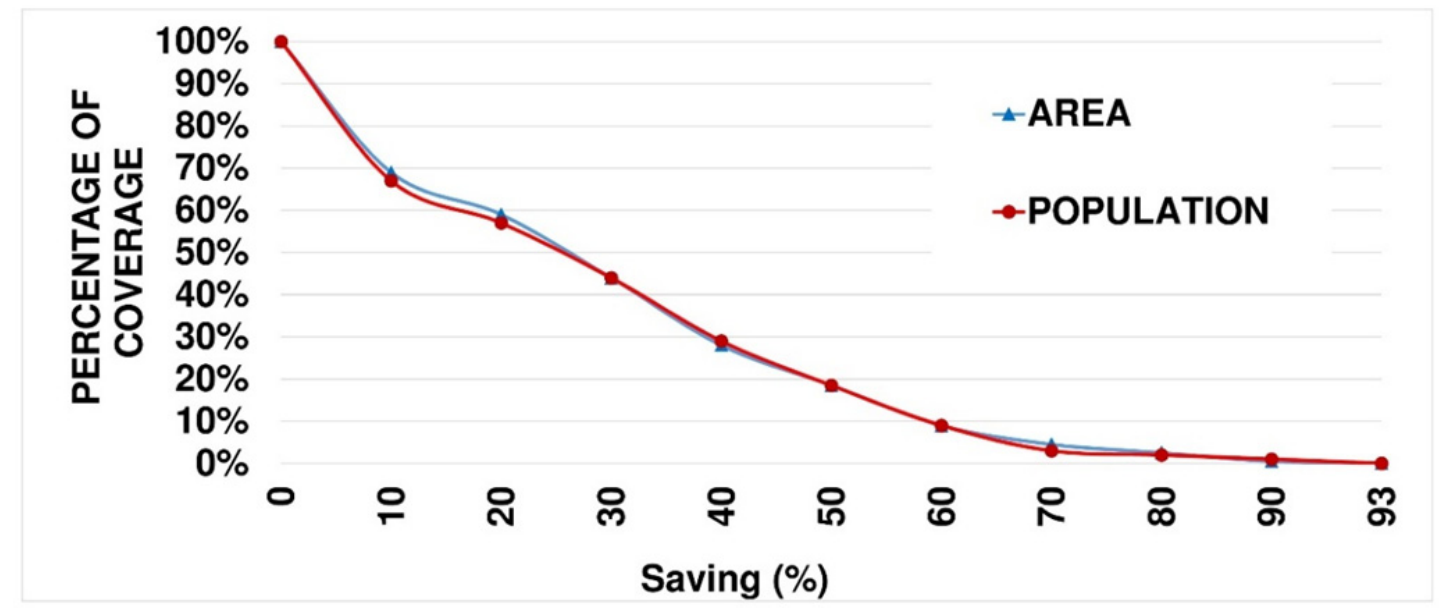

Figure 11. Percentage of savings perceived as variable for health facilities

\section{Conclusions}

As a general assessment, it is possible to affirm that the proposed interventions to the horizon 2031 on the road infrastructure network, improve the conditions of accessibility of the population towards the health care centers of the municipality, by covering more than $70 \%$ of the population in a time of up to 10 minutes.

On the other hand, the evaluation methodology allows locating areas with access difficulties, facilitating decision making in future road interventions, as well as the implementation of new equipment in order to benefit the affected population.

It is recommended to carry out, in future investigations, the intervention in health for the industrial sector destined in the municipality, considering that, it could be a potential focus of work accidents, which require to be attended.

\section{Acknowledgments}

The authors express their sincere thanks to the students and professionals assigned to the research groups on Sustainable Mobility and Urban Planning of the National University of Colombia - Manizales headquarters.

\section{Competing Interests Statement}

The authors declare that there are no competing or potential conflicts of interest.

\section{References}

Alcaldía de Pitalito. (2012). Acuerdo 024 de 2012 - Adopción del Plan de desarrollo municipal 2012-2015. Todos en Acción. Retrieved from http://cdim.esap.edu.co/BancoMedios/Documentos\%20PDF/pitalitohuilapd2012-2015.pdf

Alcaldía de Pitalito. (2015). Información general [Online]. Retrieved March 21, 2018, from http://www.alcaldiapitalito.gov.co/web1/index.php/pitalito/informacion-genera

Bocarejo, J. P., \& Oviedo, D. R. (2012). Transport accessibility and social inequities: a tool for identification of mobility needs and evaluation of transport investments. Journal of Transport Geography, 24, 142-154, https://doi.org/10.1016/j.jtrangeo.2011.12.004

Cheng, J., Bertolini, L., \& Clercq, F. (2007). Measuring Sustainable Accessibility. Transportation research Board: Journal of the Transportation Research Board, 2017, 16-25. https://doi.org/10.3141/2017-03 
Consorcio Aguas del Huila. (2014). Consultoría para la elaboración de los estudios y dise-os de los sistemas de agua potable y alcantarillado de la zona urbana, que fueren necesarios del municipio de Pitalito, departamento del Huila. Producto I componente de agua potable informe 5 dise-os definitivos..

Departamento Administrativo Nacional de Estadística - DANE. (2015). Estimación y proyección de la población nacional, departamental y municipal por área 1985-2020 [online]. Retrieved March 13, 2018, from: https://www.dane.gov.co/index.php/estadisticas-por-tema/demografia-y-poblacion/proyecciones-de-poblaci

Engwicht, D. (1993). Reclaiming Our Cities and Towns: Better Living with Less Traffic. Gabriola Island: New Society Publishers, Limited.

Gellrich, M., \& Zimmermann, N. (2007). Investigating the regional-scale pattern of agricultural land abandonment in the Swiss mountains: A spatial statistical modelling approach. Landscape and Urban Planning, 79, 65-76. https://doi.org/10.1016/j.landurbplan.2006.03.004

Hansen, W. (1959). How accessibility shapes land use. Journal of the American Institute of Planners, 25(2), 73-76. https://doi.org/10.1080/01944365908978307

Montoya, J., Escobar, D., \& Moncada, C. (2017). Proposed location of new shopping centers, application of an urban territorial accessibility analysis. Revista Espacios, 38(51), 4. Retrieved from http://www.revistaespacios.com/a17v38n51/17385104.html

Montoya, J., Escobar D., \& Sabogal, O. (2017). Donde ubicar nuevos nodos comerciales en la ciudad de Manizales - Colombia? Aplicación de un análisis geográfico. Revista Espacios, 38(53), 7. http://www.revistaespacios.com/a17v38n53/a17v38n53p07.pdf

Monzón de Cáceres, A. (1988). La Accesibilidad individual como elemento de evaluación de los planes de transporte en la comunidad de Madrid/Espa-a. Informes de la Construcción, 40(396), 21-39. https://doi.org/10.3989/ic.1988.v40.i396.1549

Morris, J., Dumble, P., \& Wigan, M. (1978). Accessibility indicators for transport planning. Transportation Research A, 13A, 91-109. https://doi.org/10.1016/0191-2607(79)90012-8

Perilla, J., Escobar, D., \& Cardona S. (2018). New transportation infrastructure impact in terms of global average access - intersection \&quot;la carola\&quot; manizales (colombia) case study. Contemporary Engineering Sciences, Hikari, 11(5), 215-227. https://doi.org/10.12988/ces.2018.812

Putri, K. Y., Permanasari, A. E., \& Fauziati, S. (2016). Pattern of Accesibility Level of Health Facilities in Yogyakarta, Biomedical Engineering (IBIOMED), International Conference, 1-6. https://doi.org/10.1109/IBIOMED.2016.7869830

Rosero, L. (2004). Spatial access to healt care in Costa Rica and its equity: a GIS-based study. Social Science \& Medicine, 58, 1271-1284. https://doi.org/10.1016/S0277-9536(03)00322-8

Sallán, J., Guardiet, J., \& Su-é, A. (2010). Métodos cuantitativos de organización industrial I, Barcelona. Ediciones de la Universidad Politécnica de Catalunya, 159.

Unal, E., Chen, S. E., \& Waldorf, B. S. (2007). Spatial accessibility of healt care in Indiana, Working Papers 07-07, Purdure University. Retrieved from https://www.researchgate.net/profile/Susan_Chen4/publication/5218837_Spatial_Accessibility_Of_Health_ Care_In_Indiana/links/00b7d51912d87cda90000000.pdf

Vega, A. (2011). A multi-modal approach to sustainable accessibility in Galway. Regional Insights, 2(2), 15-17. https://doi.org/10.1080/20429843.2011.9727923

Zuluaga J. D., \& Escobar, D. (2016). Geomarketing Analysis for Shopping Malls in Manizales (Colombia). Accessibility approach methodology. Revista Espacios, 38(21), 20. Retrieved from http://www.revistaespacios.com/a17v38n21/17382120.html

\section{Copyrights}

Copyright for this article is retained by the author(s), with first publication rights granted to the journal.

This is an open-access article distributed under the terms and conditions of the Creative Commons Attribution license (http://creativecommons.org/licenses/by/4.0/). 